\title{
ВЛИЯНИЕ МЕСТНЫХ КОРМОВЫХ ДОБАВОК НА БИОХИМИЧЕСКИЕ ПОКАЗАТЕЛИ СЫВОРОТКИ КРОВИ СИММЕНТАЛЬСКОЙ ПОРОДЫ В УСЛОВИЯХ ЯКУТИИ
}

\author{
N.M. Alekseeva, P.P. Borisova, N.A. Nikolaeva
}

\section{THE INFLUENCE OF LOCAL FODDER ADDITIVES ON BIOCHEMICAL INDICES OF BLOOD SERUM OF SIMMENTAL BREED IN THE CONDITIONS OF YAKUTIA}

Алексеева Ньургустана Михайловна - канд. с.-х. наук, ст. науч. сотр. лаб. селекции и разведения крупного рогатого скота Якутского НИИ сельского хозяйства им. М.Г. Сафронова, г. Якутск. E-mail: agronii71@mail.ru

Борисова Парасковья Прокопьевна - канд. С.-х. наук, ст. науч. сотр. лаб. селекции и разведения крупного рогатого скота Якутского НИИ сельского хозяйства им. М.Г. Сафронова, г. Якутск.

E-mail: Sulusovna@mail.ru

Николаева Наталия Афанасьевна - канд. с.-х. наук, вед. науч. сотр. лаб. селекции и разведения крупного рогатого скота Якутского НИИ сельского хозяйства им. М.Г. Сафрронова, г. Якутск.

E-mail: natanik_69@mail.ru

Цель исследования - получение экспериментальных данных по влиянию местных кормовых добавок на биохимические показатели сыворотки крови дойных коров симментальской породы в условиях Якутии. В научном опыте, проведенном на коровах симментальской породы, установлено положительное влияние местных кормовых добавок на биохимические показатели сыворотки крови. В наших исследованиях следует отметить, что содержание общего белка сыворотки крови подопытных животных находилось в пределах фозиологической нормы. Некоторое преимущество по содержанию общего белка обнаружено у коров II опьтной группы, ппо динамике белковых фрракций видно, что наибольшая концентрация глобулинов в сыворотке крови у коров II опытной группы за период опыта. Так, содержание $\alpha$-глобулинов в сыворотке крови составило 12,9 г/л, $\beta$-глобулинов - 9,9 и үглобулинов - 20,2 г/л. Разница между группами по содержанию альбуминов и глобулинов была незначительной $(P<0,95)$. Также содержание в сыворотке крови холестерина у коров II опыт-
Alekseeva Nyurgustana Mikhaylovna - Cand. Agr. Sci., Senior Staff Scientist, Lab. of Cattle Selection and Breeding, Yakut Scientific Research Institute of Agriculture named after M. G. Safronov, Yakutsk. E-mail: agronii71@mail.ru

Borisova Paraskovya Prokopievna - Cand. Agr. Sci., Senior Staff Scientist, Lab. of Cattle Selection and Breeding, Yakut Scientific Research Institute of Agriculture named after M. G. Safronov, Yakutsk.

E-mail: Sulusovna@mail.ru

Nikolaeva Natalia Afanasyevna - Cand. Agr. Sci., Leading Staff Scientist, Lab. of Cattle Selection and Breeding, Yakut Scientific Research Institute of Agriculture named after M. G. Safronov, Yakutsk.

E-mail: natanik_69@mail.ru

ной группы была больше на 7,95 ммоль/л, чем у коров контрольной, и на 1,24 ммоль/л, чем у коров I опытной группы. Проведенные исследования показали, что изменение содержания белка и егео фрракций в сыворотке крови свидетельствует об усилении обменных процессов в организме коров симментальской породы. Использование в составе основного рациона кормления кормовых добавок из местного сырья оказало определенное влияние на минеральный состав сыворотки крови животных. $K$ концу опыта в сыворотке крови коров контрольной группы уровень кальщия составил 12,76 г/\%, фоосфоро 4,62 мг/\%, в крови коров I и II опьтных групn - 12,71 г/\% и 4,66 м2/\%; 12,80 г/\% и 4,67 мг/\% соответственно. Эти даннье свидетельствуют о нормализации минерального обмена у животных и отсутствии у них остеомаляции. Следует отметить, что у коров II опытной группы наблюдалась тенденция увеличения состава аминокислот. $B$ начале периода опыта содержание лизина в крови повысилось на 5,22 мг/\% по сравнению с контролем и на 5,79 мг/\% ссо I/ опытной груп- 
пой, метионина на 19,67 и на 10,02 м2/\% coomветственно. Такая же закономерность и по остальному составу аминокислот и в коние проведения опыта. Полученные данные Ісвидетельствуют, что оптимизация кормовых рационов коров симментальской породы। по содержанию витаминов группы $A$ u $C$ за счет применения мместных кормовых добавок оказала положительное влияние на кроветворную функцию.

Ключевые слова: кормовая добавка, кровь, минеральный ссостав, пробиотик, пивная дробина, глобулины, фоосфрор, калий.

The purpose of the study was to obtain experimental data on the influence of local feed additives on biochemical parameters of blood serum of dairy cows of the Simmental breed in the conditions of Yakutia. In scientific experiment conducted on the cows of Simmental breed positive effect of local feed additives on biochemical parameters of blood serum was established. It should be noted that in our studies the total protein content of the blood serum of experimental animals was within physiological norm. A certain advantage in the content of total protein was found in the cows of the second experimental group; the dynamics of protein fractions showed that the highest concentration of globulins in blood serum had been in the cows of the second experimental group for the period of the experiment. So the content of a-globulins in blood serum was $12.9 \mathrm{~g} / \mathrm{l}$, $\beta$-globulins was 9.9 and $y$-globulins was $20.2 \mathrm{~g} / \mathrm{l}$. The difference between the groups in the content of albumin and globulin was insignificant $(P<0.95)$. Also, the serum cholesterol content in the cows of the second experimental group was $7.95 \mathrm{mmol} / \mathrm{l}$ higher than that of the control cows and $1.24 \mathrm{mmol} / \mathrm{l}$ more than the cows of the first experimental group. Conducted studies showed that the change in the content of protein and its fractions in blood serum had had an increase in metabolic processes in the body of the cows of Simmental breed. Using feed additives from local raw materials in the main feeding ration had a definite effect on mineral composition of animal blood serum. By the end of the experiment, the level of calcium in the blood serum of cows in the control group was $12.76 \mathrm{~g} / \%$, phosphorus made $4.62 \mathrm{mg} / \%$, in the blood of cows of the first and second experimental groups was $12.71 \mathrm{~g} / \%$ and $4.66 \mathrm{mg} / \% ; 12.80 \mathrm{~g} / \%$ and $4.67 \mathrm{mg} / \%$, respectively. These data indicate the normalization of mineral me- tabolism in animals and the absence of osteomalacia in them. It should be noted that the cows of the second experimental group showed the tendency of increasing the content of amino acids. At the beginning of the test the blood lysine content increased by $5.22 \mathrm{mg} / \%$ compared with the control and by $5.79 \mathrm{mg} / \%$ with the second experimental group, methionine by 19.67 and $10.02 \mathrm{mg} / \%$, respectively. The same pattern can be also applied to the rest of amino acids' content at the end of the experiment. The data obtained indicated that the optimization of feed rations for Simmental cows by the content of vitamins $A$ and $C$ by means of using local feed additives had had a positive effect on hematopoietic function.

Keywords: feed additive, blood, mineral composition, probiotic, beer pellet, globulins, phosphorus, potassium.

Введение. Климатические условия Якутии сильно отличаются своей суровостью, недостаточно эффективной температурой для растений и сильной засушливостью, что непозволяет заготавливать корма для крупного рогатого скота высокого качества в необходимых объемах. Это ведет к дефициту кормового протеина, витаминов, углеводов, жиров, микро- и макроэлементов в рационе сельскохозяйственных животных, особенно в зимний период при длительном стойловом содержании. Неполноценность и несбалансированность рационов приводят к снижению продуктивности и патологиям у животных всех возрастных групп [1].

За последние годы в кормлении животных применяется большое количество кормовых добавок и препаратов, содержащих в себе белки, аминокислоты, витамины, макро- и микроэлементы и другие биологически активные вещества. Они используются для балансирования рационов по недостающим элементам питания, улучшения поедаемости основных кормов, повышения переваримости и использования питательных веществ рационов, целенаправленного изменения обмена веществ и профилактики стрессовых состояний животных. Все добавки имеют специфические свойства и в зависимости от дозы поразному влияют на организм животных. Их применение должно быть основано на глубоком знании их действия на организм и технологии применения в кормлении животных [2, 3]. 
Якутский НИИСХ разработал целый ряд инновационных пробиотических препаратов на основе биологически активных, уникальных местных природных штаммов бактерий Bacillus subtilis, таких как «Сахабактисубтил» (утв. Россельхознадзором МСX РФ, 14.11.2006 г.), «Норд-Бакт», «Хонгуринобакт», «Пантобакт», которые являются активными индукторами эндогенного интерферона, повышают иммунобиологическую реактивность и корректируют обмен веществ организма, улучшают переваримость и усвояемость кормов, способствуют увеличению живой массы. Препарат «Хонгуринобакт» способствует нормализации микробиоценоза, увеличению количества бифидо- и лактобактерий, повышению иммунобиологической реактивности организма, продуктивности сельскохозяйственных животных [4]. Научными опытами доказано, что природные цеолиты оказывают положительное влияние на процесс пищеварения и повышают усвояемость кормов из-за содержания в них легкоусвояемых форм кальция, калия, микроэлементов: кобальта, меди, цинка и других химических веществ, весьма необходимых организму сельскохозяйственных животных. Овес «Покровский» - выведенный якутскими селекционерами сорт овса. Широко применяется в кормлении сельскохозяйственных животных, считается чрезвычайно ценным компонентом комбикормов, так как сравнительно богат протеином и незаменимыми аминокислотами. По химическому составу овес имеет 86,7 \% сухих веществ, в т.ч. 10,8 \% протеина, 4,59 \% жиpa, 10,5 \% клетчатки, 69,8 \% БЭВ и 4,2 \% золы.

Ячмень «Тамми» - одно из наиболее древних культурных растений, приспособленных к самым разнообразным почвенно-климатическим условиям и имеющих исключительную скороспелость. К тому же имеет высокие кормовые достоинства. Белок в его зерне оптимально сбалансирован по аминокислотному составу, что имеет решающее значение для рационального, экономного расходования кормов.

На сегодняшний день применение местных кормовых добавок для крупного рогатого скота, обеспечивающих повышение продуктивности, улучшение состояния здоровья, поедаемости и усвоения кормов, является весьма актуальным.

Цель исследования. Получение экспериментальных данных по влиянию местных кормовых добавок на биохимические показатели сыворотки крови дойных коров симментальской породы в условиях Якутии.

Задачи исследования: изучить биохимические показатели сыворотки крови подопытных животных.

Объекты и методы исследования. Впервые в условиях Якутии изучается применение новых кормовых добавок, пробиотиков для коров симментальской породы, обеспечивающих их полноценное кормление.

Полученные данные по применению местных кормовых добавок будут использоваться в крестьянских, фермерских хозяйствах Руспублики Саха (Якутия).

Для определения влияния местных кормовых добавок при кормлении коров симментальской породы был проведен научно-хозяйственный опыт в ООО «Хоробут» Мегино-Кангаласского улуса Республики Саха (Якутия). Объектом исследований являлись коровы симментальской породы.

Были сфрормированы 3 группы подопытных животных по 10 голов в каждой по принципу аналогов по породе, возрасту и живой массе соответственно. Продолжительность научнохозяйственного опыта составила 238 дней: с 4 фревраля по 29 сентября 2019 г. Содержание животных в группе было одинаковым, в зимнее время находились в молочном репродукторе на привязном содержании. Кормление производилось два раза в сутки. В течение всего научнохозяйственного опыта в стойловый период подопытные животные всех групп получали сбалансированный рацион в соответствии с детализированной системой кормления. Для подопытных групп были составлены рационы, одинаковые по основным питательным веществам, разработанные А.П. Калашниковым и др. [5, 6].

Для определения состояния организма подопытных животных в течение опыта исследовали биохимию крови [7]. При исследовании фризиологического состояния животных учитывали общее фризиологическое состояние, состав крови по форменным элементам, белковым фракциям, микро-макроэлементам, витаминному, аминокислотному составу в лаборатории переработки сельскохозяйственной продукции и биохимических анализов ФГБУН «Якутский НИИСХ им. М.Г. Сафрронова» методом ближней инфракрасной спектроскопии на SpectraStar 2200. 
Результаты исследования и их обсуждение. Биохимические показатели крови взаимосвязаны с ростом, развитием, продуктивными и племенными качествами сельскохозяйственных животных и во многом объясняют возрастные и генетические различия в становлении этих процессов. Кровь является тканью, в которой отражаются все наиболее важные жизненно важные процессы в организме. Свойства крови подвержены постоянным изменениям в зависимости от состояния организма. Огромное влияние на биохимические показания оказывают внешние фракторы, в том числе и кормление животных $[8,9]$.
Главную функцию в животном организме выполняют белки, они служат пластическим материалом для построения тканей, выполняют защитную фуннкцию организма, поддерживают осмотическое давление.

С целью оценки состояния организма подопытных животных и обменных процессов определили содержание белковых фракций крови в начале и конце опыта (табл. 1).

В наших исследованиях концентрация белка и его фрракций в сыворотке крови коров всех групп находилась в пределах физиологической нормы, общее содержание белка и его фрракций представлено в таблице 1.

\section{Содержание общего белка и его фракций в сыворотке крови коров симментальской породы (M士m)}

\begin{tabular}{|l|c|c|c|c|}
\hline \multirow{2}{*}{ Показатель } & Период & \multicolumn{3}{|c|}{ Группа } \\
\cline { 3 - 5 } & опыта & Контрольная & І опытная & I опытная \\
\hline \multirow{2}{*}{ Общий белок, г/л } & Начало & $68,7 \pm 0,04$ & $65,2 \pm 0,10$ & $76,1 \pm 0,02$ \\
\cline { 2 - 5 } & Конец & $73,0 \pm 0,08$ & $72,0 \pm 0,09$ & $77,0 \pm 0,05$ \\
\hline \multirow{2}{*}{ Альбумины, г/л } & Начало & $23,2 \pm 0,04$ & $23,2 \pm 0,04$ & $25,0 \pm 0,06$ \\
\cline { 2 - 5 } & Конец & $26,3 \pm 0,03$ & $24,3 \pm 0,07$ & $26,2 \pm 0,03$ \\
\hline \multirow{2}{*}{ а-глобулин, г/л } & Начало & $12,3 \pm 0,01$ & $12,6 \pm 0,05$ & $12,7 \pm 0,02$ \\
\hline \multirow{2}{*}{ К-глобулин, г/л } & Конец & $12,8 \pm 0,05$ & $12,4 \pm 0,03$ & $12,9 \pm 0,04$ \\
\hline \multirow{2}{*}{ ү-глобулин, г/л } & Начало & $10,2 \pm 0,07$ & $9,7 \pm 0,08$ & $9,5 \pm 0,02$ \\
\cline { 2 - 5 } & Конец & $10,5 \pm 0,02$ & $10,1 \pm 0,02$ & $9,9 \pm 0,05$ \\
\hline \multirow{2}{*}{ Холестерин, ммоль/л } & Начало & $21,7 \pm 0,03$ & $20,2 \pm 0,06$ & $20,0 \pm 0,01$ \\
\cline { 2 - 5 } & Конец & $20,2 \pm 0,02$ & $19,7 \pm 0,06$ & $20,2 \pm 0,02$ \\
\cline { 2 - 5 } & Начало & $99,1 \pm 4,20$ & $101,3 \pm 2,13$ & $100,3 \pm 3,38$ \\
\hline
\end{tabular}

Примечание: $\mathrm{P}<0,95$.

Анализируя данные таблицы 1, следует отметить, что содержание общего белка сыворотки крови подопытных животных находилось в пределах физиологической нормы. Некоторое преимущество по содержанию общего белка обнаружено у коров II опытной группы, по динамике белковых фракций видно, что наибольшая концентрация глобулинов в сыворотке крови у коров II опытной группы за период опыта. Так содержание а-глобулинов в сыворотке крови составило 12,9 г/л, $\beta$-глобулинов - 9,9 г/л и ү-глобулинов 20,2 г/л. Разница между группами по содержанию альбуминов и глобулинов была незначительной $(P<0,95)$. Также содер- жание в сыворотке крови холестерина у коров II опытной группы была больше на 7,95 ммоль/л, чем у коров контрольной, и на 1,24 ммоль/л, чем у коров I опытной группы. Проведенные исследования показали, что изменение содержания белка и его фракций в сыворотке крови свидетельствует об усилении обменных процессов в организме коров симментальской породы.

Использование в составе основного рациона кормления местных кормовых добавок из местного сырья оказало определенное влияние на минеральный состав сыворотки крови животных (табл. 2). 


\section{Минеральный состав сыворотки крови коров симментальской

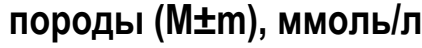

\begin{tabular}{|c|c|c|c|c|c|c|}
\hline \multirow{3}{*}{ Показатель } & \multicolumn{6}{|c|}{ Группа } \\
\hline & \multicolumn{2}{|c|}{ Контрольная } & \multicolumn{2}{|c|}{ І опытная } & \multicolumn{2}{|c|}{ II опытная } \\
\hline & $\begin{array}{c}\text { В начале } \\
\text { опыта }\end{array}$ & $\begin{array}{c}\text { В конце } \\
\text { опыта }\end{array}$ & $\begin{array}{c}\text { В начале } \\
\text { опыта }\end{array}$ & $\begin{array}{c}\text { В конце } \\
\text { опыта }\end{array}$ & $\begin{array}{c}\text { В начале } \\
\text { опыта }\end{array}$ & $\begin{array}{c}\text { В конце } \\
\text { опыта }\end{array}$ \\
\hline Кальций & $98,47 \pm 0,02$ & $97,32 \pm 0,06$ & $98,23 \pm 0,07$ & $99,13 \pm 0,06$ & $99,86 \pm 0,14$ & $100,32 \pm 0,07$ \\
\hline Фосфрор & $92,43 \pm 0,01$ & $94,61 \pm 0,08$ & $95,64 \pm 0,05$ & $96,65 \pm 0,08$ & $100,1 \pm 0,1$ & $101,2 \pm 0,08$ \\
\hline Магний & $29,42 \pm 0,06$ & $28,75 \pm 0,03$ & $28,78 \pm 0,09$ & $29,47 \pm 0,12$ & $30,23 \pm 0,1$ & $31,21 \pm 0,27$ \\
\hline Железо & $87,23 \pm 0,5$ & $88,12 \pm 0,5$ & $89,65 \pm 0,6$ & $88,23 \pm 0,78$ & $89,17 \pm 1,53$ & $89,62 \pm 1,9$ \\
\hline Хлор & $356,21 \pm 0,3$ & $358,32 \pm 0,43$ & $361,32 \pm 0,35$ & $369,23 \pm 0,42$ & $367,23 \pm 1,42$ & $368,12 \pm 0,67$ \\
\hline Калий & $176,32 \pm 0,1$ & $182,36 \pm 0,43$ & $183,87 \pm 0,3$ & $185,23 \pm 0,36$ & $186,23 \pm 0,2$ & $187,21 \pm 0,31$ \\
\hline Натрий & $315,62 \pm 0,2$ & $319,3 \pm 0,3$ & $323,84 \pm 0,64$ & $321,64 \pm 0,28$ & $323,64 \pm 2,3$ & $324,03 \pm 1,35$ \\
\hline
\end{tabular}

Примечание: $\mathrm{P}>0,04$.

Данные таблицы 2 показали, что содержание кальция в период проведения опыта колеблется от 97,32 до 98,47 ммоль/л у коров контрольной группы, от 98,23 до 99,13 ммоль/л у коров I опытной группы и от 99,86 до 100,32 ммоль/л у коров II опытной группы, что в целом соответствовало норме. Соответственно содержание неорганического фосффора было в пределах нормы, с колебаниями от 92,43 до 94,61 ммоль/л у коров контрольной группы, от 95,64 до 96,65 ммоль/л у І опытной группы и от 100,12 до 101,21 у коров II опытной группы. В целом между группами содержание кальция и фросфора в сыворотке крови достоверных различий не имело.

Такая же тенденция и по содержанию фосфора, магния, железа, хлора, калия и натрия. Достоверной разницы по содержанию магния, хлора, калия, натрия и железа в сыворотке крови сравниваемых групп подопытных животных не установлено, что соответствует физиологической норме для данного вида и возраста животных.

В наших исследованиях введение в рацион коров местных кормовых добавок позволило сбалансировать рационы по минеральным ве- ществам. К концу опыта в сыворотке крови коров контрольной группы уровень кальция составил 12,76 г/\%, фросфрора 4,62 мг/\%, в крови коров | и || опытных групп - 12,71 г/\% и 4,66 мг/\%; 12,80 г/\% и 4,67 мг $/ \%$ соответственно. Эти данные свидетельствуют о нормализации минерального обмена у животных и отсутствии у них остеомаляции.

Следует отметить, что у коров ॥ опытной группы наблюдалась тенденция увеличения состава аминокислот. В начале опыта содержание лизина в крови повысилось на 5,22 мг $\%$ по сравнению с контролем и на 5,79 мг $\%$ со II опытной группой, метионина - на 19,67 и 10,02 мг $/ \%$ соответственно. Такая же закономерность и по остальному составу аминокислот и в конце проведения опыта. Полученные данные свидетельствуют, что оптимизация кормовых рационов коров симментальской породы по содержанию витаминов группы $\mathrm{A}$ и $\mathrm{C}$ за счет применения местных кормовых добавок оказала положительное влияние на кроветворную фуннцию. Так, если содержание витаминов A и C на начало опыта было меньше, то в конце опыта эти же показатели нормализовались (табл. 3). 
Аминокислотный и витаминный состав сыворотки крови коров симментальской породы $(\mathrm{M} \pm \mathrm{m})$

\begin{tabular}{|l|c|c|c|c|c|c|}
\hline \multirow{2}{*}{ Показатель } & \multicolumn{3}{|c|}{ Круппа } \\
\cline { 2 - 7 } & \multicolumn{2}{|c|}{ Контрольная } & \multicolumn{2}{c|}{ І опытная } & \multicolumn{2}{c|}{ І опытная } \\
\cline { 2 - 7 } & $\begin{array}{c}\text { В начале } \\
\text { опыта }\end{array}$ & $\begin{array}{c}\text { В конце } \\
\text { опыта }\end{array}$ & $\begin{array}{c}\text { В начале } \\
\text { опыта }\end{array}$ & $\begin{array}{c}\text { В конце } \\
\text { опыта }\end{array}$ & $\begin{array}{c}\text { В начале } \\
\text { опыта }\end{array}$ & $\begin{array}{c}\text { В начале } \\
\text { опыта }\end{array}$ \\
\hline Лизин, мг/\% & $562,0 \pm 0,07$ & $544,2 \pm 0,1$ & $561,5 \pm 0,04$ & $560,79 \pm 0,06$ & $567,3 \pm 0,06$ & $626,5 \pm 0,09$ \\
\hline Лейцин, мг/\% & $17,9 \pm 0,04$ & $21,1 \pm 0,17$ & $18,23 \pm 0,07$ & $19,71 \pm 0,05$ & $18,23 \pm 0,17$ & $20,32 \pm 0,19$ \\
\hline Метионин, мг/\% & $261,6 \pm 0,05$ & $262,6 \pm 0,09$ & $271,3 \pm 0,09$ & $278,47 \pm 0,06$ & $281,32 \pm 0,06$ & $342,31 \pm 0,07$ \\
\hline Триптофран, мг/\% & $7,23 \pm 0,09$ & $7,33 \pm 0,06$ & $7,42 \pm 0,08$ & $7,52 \pm 0,07$ & $7,22 \pm 0,07$ & $7,32 \pm 0,17$ \\
\hline Цистин, мг/\% & $749,2 \pm 0,01$ & $753,2 \pm 0,04$ & $766,3 \pm 0,09$ & $772,93 \pm 0,06$ & $824,06 \pm 0,14$ & $836,12 \pm 0,1$ \\
\hline $\begin{array}{l}\text { Витамин А, } \\
\text { мкг/100мл }\end{array}$ & $36,23 \pm 0,4$ & $44,12 \pm 0,3$ & $42,5 \pm 0,28$ & $44,9 \pm 1,23$ & $44,73 \pm 1,98$ & $45,89 \pm 2,23$ \\
\hline Витамин С, мг/\% & $3,42 \pm 0,42$ & $3,62 \pm 0,41$ & $4,33 \pm 0,09$ & $4,44 \pm 0,03$ & $4,53 \pm 0,04$ & $5,46 \pm 0,09$ \\
\hline
\end{tabular}

Выводы. Полученные данные свидетельствуют, что использование местных кормовых добавок в кормлении коров симментальской породы показало, что в крови подопытных животных не выявлено статически достоверных различий в биохимических, минеральных показателях, характеризующих состояние белкового, минерального обменов. Это свидетельствует о положительном влиянии местных кормовых добавок на состояние обменных процессов и здоровья животных в целом.

\section{Литература}

1. Алексеева Н.М., Николаева Н.А., Борисова П.П. Использование фрерментного препарата при кормлении дойных коров в условиях Якутии // Кормление сельскохозяйственных животных и кормопроизводство. 2013. № 10. C. 59-63.

2. Алексеева Н.М., Борисова П.П. Влияние биологической кормовой добавки на переваримость питательных веществ корма у коров симментальской пород // Главный зоотехник. 2015. № 8. С. 24-29.

3. Алексеева Н.М., Романова В.В., Борисова П.П. Биохимические показатели крови молодняка герефородской породы крупного рогатого скота в условиях Якутии // Вестник КрасГАУ. 2017. № 7. С. 37-43.

4. Неустроев М.П., Третьяков И.С., Сазонов Н.Н. Природные цеолиты хонгуринского месторождения в животноводстве и ветеринарии / Рос. акад. с.-х. наук, Якут. НИИ сельского хозяйства. Якутск, 2008. 148 с.

5. Нормы и рационы кормления сельскохозяйственных животных / А.П. Калашников, И.Н. Клейменов, В.Н. Баканов [и др.]. М.: Агропромиздат, 1985. 352 с.

6. Кузьмина И.Ю. Кормовые добавки для молодняка крупного рогатого скота в условиях Магаданской области // Фундаментальные и прикладные аспекты кормления сельскохозяйственных животных и технологии кормов: мат-лы конф., посв. 120-летию М.Ф. Томмэ (4-16 июня, 2016 г.). Дубровицы: ВИЖ им. Л.К. Эрнста, 2016. С. 129-134.

7. Овсянников А.И. Основы опытного дела в животноводстве. М.: Колос, 1976. С. 43-60.

8. Арнатовский И.Д. Генетические основы и проблемы зональной селекции в скотоводстве // Проблемы зоотехнии, ветеринарии и биологии сельскохозяйственных животных на Дальнем Востоке: сб. науч. тр. ДальГАУ. Благовещенск: ДальГАУ, 2001. С. 35-42.

9. Алексеева Н.М., Николаева Н.А., Борисова П.П. Использование ферментного препарата при кормлении дойных коров в условиях Якутии // Кормление сельскохозяйственных животных и кормопроизводство. 2013. № 10. C. 59-63. 


\section{Literatura}

1. Alekseeva N.M., Nikolaeva N.A., Borisova P.P. Ispol'zovanie fermentnogo preparata pri kormlenii dojnyh korov v uslovijah Jakutii // Kormlenie sel'skohozjajstvennyh zhivotnyh i kormoproizvodstvo. 2013. № 10. S. 59-63.

2. Alekseeva N.M., Borisova P.P. Vlijanie biologicheskoj kormovoj dobavki na perevarimost' pitatel'nyh veshhestv korma u korov simmental'skoj porod // Glavnyj zootehnik. 2015. № 8. S. 24-29.

3. Alekseeva N.M., Romanova V.V., Borisova P.P. Biohimicheskie pokazateli krovi molodnjaka gereforodskoj porody krupnogo rogatogo skota v uslovijah Jakutii // Vestnik KrasGAU. 2017. № 7. S. 37-43.

4. Neustroev M.P., Tret'jakov I.S., Sazonov N.N. Prirodnye ceolity hongurinskogo mestorozhdenija v zhivotnovodstve i veterinarii / Ros. akad. s.-h. nauk, Jakut. NII sel'skogo hozyaistva. Jakutsk, 2008. $148 \mathrm{~s}$.

5. Normy i raciony kormlenija sel'skohozjajstvennyh zhivotnyh / A.P. Kalashnikov, I.N. Klejme- nov, V.N. Bakanov [i dr.]. M.: Agropromizdat, 1985. $352 \mathrm{~s}$.

6. Kuz'mina I.Ju. Kormovye dobavki dlja molodnjaka krupnogo rogatogo skota $v$ uslovijah Magadanskoj oblasti // Fundamental'nye i prikladnye aspekty kormlenija sel'skohozjajstvennyh zhivotnyh i tehnologii kormov: mat-ly konf., posv. 120-letiju M.F. Tommje (4-16 ijunja, 2016 g.). Dubrovicy: VIZh im. L.K. Jernsta, 2016. S. 129-134.

7. Ovsjannikov A.I. Osnovy opytnogo dela v zhivotnovodstve. M.: Kolos, 1976. S. 43-60.

8. Arnatovskij I.D. Geneticheskie osnovy i problemy zonal'noj selekcii v skotovodstve /I Problemy zootehnii, veterinarii i biologii sel'skohozjajstvennyh zhivotnyh na Dal'nem Vostoke: sb. nauch. tr. Dal'GAU. Blagoveshhensk: Dal'GAU, 2001. S. 35-42.

9. Alekseeva N.M., Nikolaeva N.A., Borisova P.P. Ispol'zovanie fermentnogo preparata pri kormlenii dojnyh korov v uslovijah Jakutii // Kormlenie sel'skohozjajstvennyh zhivotnyh i kormoproizvodstvo. 2013. № 10. S. 59-63. 